\title{
Production of cocona and jurubeba seedlings in different types of containers
}

\author{
Marcelo A Guimarães ${ }^{1}$; Manuel Filipe N Garcia²; Leandro A Damasceno ${ }^{3}$; Caris S Viana ${ }^{2}$ \\ ${ }^{1}$ UFC, Centro de Ciências Agrárias e do Ambiente, Depto. Fitotecnia, 60356-001 Fortaleza-CE; mguimara@ufc.br (autor para cor- \\ respondência); ${ }^{2}$ UFAM, Inst. Natureza e Cultura, Colegiado de Ciências Agrárias e do Ambiente, 69630-000 Benjamin Constant-AM; \\ tonantas@yahoo.com.br; carisviana@hotmail.com; 3UFAM-FCA,69077-000 Manaus-AM; leandro@agronomo.eng.br
}

\begin{abstract}
The effect of different containers was evaluated to produce cocona seedlings (Solanum sessiliflorum) and jurubeba (Solanum paniculatum). The experiment was performed in the mesoregion of Alto Solimões, in Benjamin Constant, Amazonas state, Brazil, in a particular production area. The seeding was done in black holed polyethylene bags and polystyrene trays with 128,200 and 288 cells with volumes of $250.00 ; 32.61 ; 21.60$ and $9.88 \mathrm{~cm}^{3}$, respectively. We adopted a completely randomized design with four containers, four replicates, being assessed five plants per replicate. The seedlings of cocona were evaluated at 27,38, 45 and 52 days after sowing (DAS) and of jurubeba at $38,45,52,59$ and 66 DAS. We evaluated the number of leaves; length of the main root, the aerial and total parts of the plant, fresh and dry matter of the main root, fresh and dry matter of the aerial part. There was no difference on the number of leaves of jurubeba at 45 and 66 DAS; there was no difference on the number of leaves of cocona at $52 \mathrm{DAS}$; there occurred a greater number of leaves of cocona when seeded on trays containing 200 cells; The other characteristics for both species presented higher values when the seeding was done in the plastic bags, at all evaluation dates.
\end{abstract}

Keywords: Solanum sessiliflorum, Solanum paniculatum, polystyrene, plastic bag.

\section{RESUMO}

Produção de mudas de cubiu e jurubeba em diferentes tipos de recipientes

Com o objetivo de verificar o efeito de diferentes recipientes na produção de mudas de cubiu (Solanum sessiliflorum) e jurubeba (Solanum paniculatum), foi realizado um experimento na mesorregião do Alto Solimões, município de Benjamin Constant-AM em área de produção particular. A semeadura foi realizada em sacos de polietileno preto, furados e bandejas de poliestireno expandido com 128, 200 e 288 células cujos volumes variaram de 250,00; 32,61; 21,60 e $9,88 \mathrm{~cm}^{3}$, respectivamente. Adotou-se o delineamento inteiramente casualizado com quatro recipientes em quatro repetições, sendo avaliadas cinco plantas por repetição. As mudas de cubiu foram avaliadas aos $27,38,45$ e 52 dias após a semeadura (DAS) e as de jurubeba aos $38,45,52,59$ e 66 DAS. Foram avaliados o número de folhas; comprimento da raiz principal, da parte aérea e total; massa fresca da raiz principal, da parte aérea e total; massa seca da raiz principal, da parte aérea e total por planta. Não houve diferença entre o número de folhas para a jurubeba aos 45 e 66 DAS e para o cubiu aos 52 DAS; foi maior o numero de folhas do cubiu quando semeado em bandeja de 200 células; as demais características, para ambas as espécies, foram superiores quando se semeou em sacos plásticos em todas as datas de avaliação.

Palavras-chave: Solanum sessiliflorum, Solanum paniculatum, poliestireno expandido, saco plástico.

(Recebido para publicação em 24 de outubro de 2011; aceito em 19 de setembro de 2012) (Received on October 24, 2011; accepted on September 19, 2012)

$\mathrm{T}$ he Amazon region has a great diversity of species with high nutritional, economic and therapeutic value. The species include the cocona (Solanum sessiliflorum) and the jurubeba (Solanum paniculatum), belonging to the Solanaceae family that are native to tropical America and probably originated in the Amazon basin or on the eastern slopes of the Peruvian, Colombian and Equatorial Andes (Brazil, 2010).

The cocona, known as maná, topiro and indian tomato, is found throughout the Brazilian, Peruvian and Colombian
Amazon and in the north and northeastern regions of Brazil. Recently it was introduced to São Paulo state, Brazil. Normally the species grows well in any type of poor, acid soil in the Amazon and is not greatly attacked by pests and diseases (Silva Filho et al., 1996).

The fruits are rich in iron, niacin (vitamin B3), citric acid and pectin (Silva Filho et al., 2003). They are used as foods and can be consumed fresh, as juice, and jelly (Yuyama et al., 2008; Silva et al., 2011). The cocona is used as seasoning for fish, meat and chicken dishes and in traditional medicine it is used to control high levels of cholesterol, uric acid and blood sugar (Yuyama et al., 2005). According to Yuyama et al. (2005) there are indications that the species presents compounds with pharmacological activity. From the point of view of nutrition the cocona has low energetic density, with high concentrations of food fibers and especially pectin (Yuyama et al., 2007). According to Augusto (2002) the cocona leaves and roots are used as medicine, the fruits as food and its juice as a cosmetic. 
The jurubeba, known as joá-manso, gerobeba, jupeba, juribeba, jurupeba, jurubeba-verdadeira and jurubeba is found throughout tropical America and is widely distributed in Brazil occurring from Rio Grande do Sul to Rio Grande do Norte. It flowers and fructifies practically all year (Santos Neto et al., 2006). It is a plant that infests empty plots, highway edges and degraded pastures and can occur in almost exclusive populations.

Research to understand the initial development of the species is extremely important to understand how they develop and improve the domestication method, and includes assessment of recipients for seedling production, considered a vital phase in the productive process.

According to Filgueira (2008), the lack of knowledge of more suitable technology for seedling production can lead the producer to crop practices that culminate in low productivity and fall in production (Silva \& Vizzotto, 2001).

Different types of recipients are used for seedling production (test tubes, trays, plastic bags), made from different materials (including expanded polystyrene, polypropylene) and sizes, especially expanded polystyrene trays that are the most used for seedling production (Filgueira, 2008).

Many studies with different species have been carried out with the same objective (Resende et al., 2003; Belfort et al., 2005; Brito, 2005), and the results have shown that larger recipients have allowed the seedlings to grow and develop better.

Thus the objective of the present study was to assess cocona and jurubeba seedling production in different sized recipients.

\section{MATERIAL AND METHODS}

The experiment was carried out in a private vegetable production area located in the Alto Solimões mesoregion, municipality of Benjamin Constant $\left(04^{\circ} 22^{\prime} 58^{\prime \prime} \mathrm{S}, 70^{\circ} 01^{\prime} 51^{\prime \prime} \mathrm{W}\right.$, altitude of $65 \mathrm{~m}$ ). The temperature ranges from 40 to $15^{\circ} \mathrm{C}$. The average accumulated rainfall over the year is
3,000 $\mathrm{mm}$, and the climate of the region is the wet and humid tropical type.

The cocona seeds were obtained from healthy fruits of plants cultivated in Benjamin Constant, and the jurubeba seeds were obtained from plants cultivated in Tonantins, both in Amazonas state, Brazil. Both sets of seeds used were obtained from fruits produced in the 2011 growing season. The seeds were extracted according to Lopes \& Pereira (2005), and the fruits were depulped and the seeds placed on blotting paper to remove excess moisture. Four days after depulping the seeds were sown using a complete randomized design with four replications. The treatments were: 1) plastic bags and expanded polystyrene trays with different cell quantities and volumes of $250.00 \mathrm{~cm}^{3}$ capacity plastic bag; 2) 128-cell polystyrene tray (32.61 $\mathrm{cm}^{3} /$ cell); 3) 200-cell polystyrene tray (21.60 $\mathrm{cm}^{3} /$ cell); and 4) 288-cell polystyrene tray $\left(9.88 \mathrm{~cm}^{3} /\right.$ cell $)$.

The substrates used were matured chicken bed enriched with mineral nutrients, and the chemical analysis presented $\mathrm{pH}=6.4$ in $\mathrm{H}_{2} \mathrm{O} ; \mathrm{P}=936 \mathrm{mg} /$ $\mathrm{dm}^{3} ; \mathrm{K}=876 \mathrm{mg} / \mathrm{dm}^{3} ; \mathrm{Ca}^{2+}=20.5 \mathrm{cmolc} /$ $\mathrm{dm}^{3} ; \mathrm{Mg}^{2+}=3.3 \mathrm{cmolc} / \mathrm{dm}^{3} ; \mathrm{Al}^{3+}=1.5$ $\mathrm{cmolc} / \mathrm{dm}^{3} ; \mathrm{H}+\mathrm{Al}=5.0 \mathrm{cmolc} / \mathrm{dm}^{3}$; $\mathrm{SB}=26.0 \mathrm{cmolc} / \mathrm{dm}^{3} ;$ CTC $(\mathrm{T})=31.0$ cmolc $/ \mathrm{dm}^{3} ;$ CTC $(\mathrm{t})=27.5 \mathrm{cmolc} / \mathrm{dm}^{3}$ and $\mathrm{MO}=21.8 \mathrm{dag} / \mathrm{kg}$.

Three seeds were sown per cell or plastic bag at a depth of $0.5 \mathrm{~cm}$, and the recipients were kept in a protected environment covered with $100 \mu \mathrm{m}$ thick plastic film. The soil moisture was maintained close to field capacity using a spray nozzle-type irrigator.

Seventeen days after sowing (DAS) the seedlings were thinned maintaining only one seedling per treatment, and the plants were harvested (five plants per replication) at $28,38,45$ and 52 DAS for the cocona and 38, 45, 52, 59 and 66 DAS for the jurubeba, assessing the following characteristics: number of definitive leaves per plant (NF); total plant length (TPL), total canopy length (TCL) and main root length (MRL), total plant fresh matter (TPFM), total canopy fresh matter (TCFM) and total main root fresh matter (TMRFM) total plant dry matter, total canopy dry matter
(TCDM) and total main root dry matter (TMRDM).

The results obtained were submitted to analysis of variance in the Sisvar program and the means compared by the Scott-Knott test at the level of 5\% probability. The polynomial regression curves were fitted for the effects of assessment periods on the TPL, TPDM and NF.

\section{RESULTS AND DISCUSSION}

Significant differences were observed for the cocona and jurubeba seedlings on all the assessment dates for the qualitative characteristics evaluated on all the sizes of recipients used (Tables 1 and 2). Generally, when the recipient volume was larger the growth and development of the seedlings produced was faster for both the species.

Reghin et al. (2003) researched pak choi seedlings (Brassica chinensis) assessing the effect of polystyrene trays with different sized cells and observed that when the cell size was larger in the trays used, the seedling development was greater for all the characteristics assessed, including early production, where the plants from 72-cell trays were 6 days earlier compared to the plants from seedlings produced on 288-cell trays.

For Cucumis sativus (cucumber) seedling production, Seabra Júnior et al. (2004) observed that using a greater volume of substrate resulted in greater development and earliness. In studies on melon, Bezerra \& Aquino (2003), studied the effect of the recipient size on seedling production in the species and observed that seedlings produced in recipients with greater substrate volume (68 and $100 \mathrm{~mL}$ ) presented greater development of the canopy characteristics compared to the smaller recipients (30 and $40 \mathrm{~mL}$ ).

For nursery owners and producers of determined species, obtaining seedlings more quickly that have been developed under good conditions can be considered highly advantageous (Reghin et al., 2007), because of the economy in daily seedling crop treatments, higher annual volume and earlier production. The 
Table 1. Main root length (MRL), total canopy length (TCL), total plant length (TPL), total main root fresh matter (TMRFM), total canopy fresh matter (TCFM), total plant fresh matter (TPFM), total main root dry matter (TMRDM), total canopy dry matter (TCDM), total plant dry matter (TPDM) and number of definitive leaves per plant (NF) of cocona seedlings (Solanum sessiliflorum) grown in various containers (comprimento da raiz principal (MRL), comprimento da parte aérea (TCL), comprimento total da planta (TPL), massa fresca da raiz principal (TMRFM), massa fresca da parte aérea (TCFM), massa fresca total da planta (TPFM), massa seca da raiz principal (TMRDM), massa seca da parte aérea (TCDM), massa seca total da planta (TPDM) e número de folhas (NF) de mudas de cubiu (Solanum sessiliflorum) crescidas em diferentes recipientes). Benjamin Constant, UFAM, 2011.

\begin{tabular}{|c|c|c|c|c|c|c|c|c|c|c|c|}
\hline \multirow{2}{*}{ Evaluations } & \multirow{2}{*}{ Containers } & MRL & TCL & TPL & & TCFM & TPFM & TMRDM & TCDM & TPDM & \multirow{2}{*}{ NF } \\
\hline & & \multicolumn{3}{|c|}{$(\mathrm{cm})$} & \multicolumn{6}{|c|}{$(g / p l)$} & \\
\hline \multirow{5}{*}{$1^{\text {st }}(27 \mathrm{DAS})$} & $\mathrm{PB}$ & $11.10 \mathrm{a}$ & $1.82 \mathrm{a}$ & $12.95 \mathrm{a}$ & $.082 \mathrm{a}$ & $0.390 \mathrm{a}$ & $0.472 \mathrm{a}$ & $0.008 \mathrm{a}$ & $0.040 \mathrm{a}$ & $0.048 \mathrm{a}$ & $\overline{5.58 \mathrm{a}}$ \\
\hline & $\mathrm{P} 1$ & $7.32 \mathrm{~b}$ & $1.35 \mathrm{~b}$ & $8.66 \mathrm{~b}$ & $.040 \mathrm{~b}$ & $0.105 \mathrm{~b}$ & $0.146 \mathrm{~b}$ & $0.004 \mathrm{~b}$ & $0.012 \mathrm{~b}$ & $0.017 \mathrm{~b}$ & $5.00 \mathrm{~b}$ \\
\hline & $\mathrm{P}^{2}$ & $6.72 \mathrm{~b}$ & $1.16 \mathrm{c}$ & $7.88 \mathrm{c}$ & $030 \mathrm{c}$ & $0.063 \mathrm{c}$ & $0.093 \mathrm{c}$ & $0.003 \mathrm{c}$ & $0.007 \mathrm{c}$ & $0.010 \mathrm{c}$ & $4.83 \mathrm{~b}$ \\
\hline & P3 & $88 \mathrm{c}$ & $1.06 \mathrm{c}$ & $6.95 \mathrm{~d}$ & $24 \mathrm{~d}$ & $0.046 \mathrm{c}$ & $0.070 \mathrm{~d}$ & $.002 \mathrm{~d}$ & $0.005 \mathrm{c}$ & $0.008 \mathrm{c}$ & $4.16 \mathrm{c}$ \\
\hline & $\mathrm{V}(\%$ & 8.20 & 8.49 & 5.89 & 6.01 & 11.83 & 8.35 & 7.96 & 15.39 & 10.87 & 7.74 \\
\hline \multirow{5}{*}{$2^{\text {nd }}(38 \mathrm{DAS})$} & $\mathrm{PB}$ & $22.10 \mathrm{a}$ & $2.74 \mathrm{a}$ & $24.84 \mathrm{a}$ & & $3.465 \mathrm{a}$ & 4.1 & & $7 \mathrm{a}$ & & $.50 \mathrm{a}$ \\
\hline & $\mathrm{P} 1$ & $08 \mathrm{~b}$ & $1.35 \mathrm{~b}$ & $12.43 \mathrm{~b}$ & & $0.267 \mathrm{~b}$ & $0.426 \mathrm{~b}$ & $0.015 \mathrm{~b}$ & $0.036 \mathrm{~b}$ & $0.051 \mathrm{~b}$ & $6.00 \mathrm{~b}$ \\
\hline & & $0 \mathrm{c}$ & & $9.36 \mathrm{c}$ & & & & $.006 \mathrm{c}$ & $0.016 \mathrm{c}$ & & $00 \mathrm{~b}$ \\
\hline & $\mathrm{P} 3$ & $7.24 \mathrm{c}$ & $1.06 \mathrm{c}$ & $8.30 \mathrm{~d}$ & $0.041 \mathrm{~d}$ & $0.086 \mathrm{c}$ & $0.134 \mathrm{~d}$ & $0.005 \mathrm{c}$ & $0.012 \mathrm{c}$ & $0.018 \mathrm{c}$ & $5.33 \mathrm{c}$ \\
\hline & $\mathrm{V}(\%$ & 6.63 & 8.17 & 5.15 & 4.43 & 3.96 & 2.51 & 5.07 & 7.16 & 4.77 & 6.32 \\
\hline \multirow{5}{*}{$3^{\text {rd }}(45 \mathrm{DAS})$} & PB & $27.03 \mathrm{a}$ & $5.83 \mathrm{a}$ & $33.86 \mathrm{a}$ & & $4.382 \mathrm{a}$ & $5.271 \mathrm{a}$ & $109 \mathrm{a}$ & $0.478 \mathrm{a}$ & $0.587 \mathrm{a}$ & $\overline{5.50 \mathrm{a}}$ \\
\hline & $\mathrm{P} 1$ & $11.42 \mathrm{~b}$ & $1.38 \mathrm{~b}$ & $12.80 \mathrm{~b}$ & $0.201 \mathrm{~b}$ & $0.278 \mathrm{~b}$ & $0.479 \mathrm{~b}$ & $0.017 \mathrm{~b}$ & $0.040 \mathrm{~b}$ & $0.058 \mathrm{~b}$ & $6.16 \mathrm{a}$ \\
\hline & $\mathrm{P} 2$ & $8.70 \mathrm{c}$ & $1.20 \mathrm{c}$ & $9.90 \mathrm{c}$ & $0.050 \mathrm{c}$ & $0.136 \mathrm{c}$ & $0.187 \mathrm{c}$ & $0.009 \mathrm{c}$ & $0.023 \mathrm{c}$ & $0.033 \mathrm{c}$ & $6.00 \mathrm{a}$ \\
\hline & P3 & $7.75 \mathrm{c}$ & $1.05 \mathrm{c}$ & $8.80 \mathrm{~d}$ & $0.027 \mathrm{c}$ & $0.096 \mathrm{c}$ & $0.123 \mathrm{c}$ & $0.007 \mathrm{c}$ & $0.015 \mathrm{c}$ & $0.022 \mathrm{~d}$ & $5.50 \mathrm{~b}$ \\
\hline & $\mathrm{V}(\%$ & 7.01 & 5.65 & 5.19 & .93 & 8.75 & 5.36 & 13.20 & 8.01 & 4.60 & 7.25 \\
\hline \multirow{5}{*}{$4^{\text {th }}(52 \mathrm{DAS})$} & PB & $.02 \mathrm{a}$ & $6.96 \mathrm{a}$ & $35.98 \mathrm{a}$ & $.099 \mathrm{a}$ & $5.110 \mathrm{a}$ & $9.210 \mathrm{a}$ & $0.223 \mathrm{a}$ & $0.652 \mathrm{a}$ & $0.875 \mathrm{a}$ & $3.83 \mathrm{~b}$ \\
\hline & $\mathrm{P} 1$ & $13.75 \mathrm{~b}$ & $1.58 \mathrm{~b}$ & $15.33 \mathrm{~b}$ & & $0.346 \mathrm{~b}$ & $0.644 \mathrm{~b}$ & $0.021 \mathrm{~b}$ & $0.048 \mathrm{~b}$ & $0.070 \mathrm{~b}$ & $3.33 \mathrm{~b}$ \\
\hline & $\mathrm{P} 2$ & $11.65 \mathrm{c}$ & $1.38 \mathrm{~b}$ & $13.03 \mathrm{c}$ & $1.176 \mathrm{c}$ & $0.216 \mathrm{~b}$ & $0.393 \mathrm{c}$ & $0.014 \mathrm{~b}$ & $0.030 \mathrm{c}$ & $0.044 \mathrm{c}$ & $5.83 \mathrm{a}$ \\
\hline & $\mathrm{P} 3$ & $9.05 \mathrm{~d}$ & $1.25 \mathrm{~b}$ & $10.30 \mathrm{~d}$ & $0.065 \mathrm{~d}$ & $0.140 \mathrm{~b}$ & $0.205 \mathrm{~d}$ & $0.008 \mathrm{~b}$ & $0.018 \mathrm{~d}$ & $0.026 \mathrm{~d}$ & $3.83 \mathrm{~b}$ \\
\hline & CV (\%) & 5.46 & 7.86 & 4.26 & 6.06 & 11.90 & 5.26 & 13.82 & 2.42 & 2.42 & 10.40 \\
\hline
\end{tabular}

${ }^{1}$ Means followed by the same letter, boxes in the column, for each evaluated characteristic in each date of evaluation, do not differ by the Scott-Knott test $(5 \%) ; \mathrm{ns}=$ not significant; $\mathrm{PB}=$ plastic bag $\left(250 \mathrm{~cm}^{3}\right) ; \mathrm{P} 1=$ plate of 128 cells; $\mathrm{P} 2=$ plate of 200 cells; $\mathrm{P} 3=$ plate of 288 cells (médias seguidas da mesma letra, maiúscula na coluna, para cada característica avaliada em cada data de avaliação, não diferem entre si pelo teste de Scott-Knott (5\%); ns= não significativo; $\mathrm{PB}=$ saco plástico $\left(250 \mathrm{~cm}^{3}\right) ; \mathrm{P} 1=$ bandeja de 128 células; $\mathrm{P} 2=$ bandeja de 200 células; P3= bandeja de 288 células).

polynomial regression analysis of the characteristics total length, total fresh matter and total dry matter showed that there was similar performance of the variables assessed in the treatments and that higher values were obtained when the number of days after sowing was greater, and the seedlings produced in the plastic bags showed the greatest increases.

For the number of leaves, maximum points were observed for all the treatments assessed for the cocona crop. For the jurubeba, all the treatments presented approximate leaf number values and on the last assessment date a greater number of leaves was observed on seedlings in all the treatments assessed (6.25) and there was no significant difference among the treatments.

Figures $1 \mathrm{~A}$ and $1 \mathrm{~B}$ show the total length of the cocona and jurubeba seedlings, respectively, grown in different sized recipients. Progressive increase was observed in the total length of both the species with days after sowing (DAS) that was greater in the plants produced in plastic bags.

These results corroborated those obtained by Resende et al. (2003) and Oliveira et al. (2004), who worked with the lettuce seedling production in different sized recipients filled with variable substrate volumes and observed that the larger recipients gave better conditions for growth and development to the plants of the species, and this observation became more evident as the number of days after sowing increased.

For the total fresh matter characteristic, for both the cocona (Table 1) and the jurubeba (Table 2), there was progressive accumulation in the growth phase that was greater in the seedlings developed in plastic bags, in agreement with the results obtained by Medeiros et al. (2008) who assessed tomato seedling production on polystyrene trays with different numbers of cells and observed greater leaf, stem and root fresh matter accumulation in the seedlings produced on $72-$ and 128 -cell polystyrene trays compared to 200-cell trays. 
Table 2. Main root length (MRL), total canopy length (TCL), total plant length (TPL), total main root fresh matter (TMRFM), total canopy fresh matter (TCFM), total plant fresh matter (TPFM), total main root dry matter (TMRDM), total canopy dry matter (TCDM), total plant dry matter (TPDM) and number of definitive leaves per plant (NF) of jurubeba seedlings (Solanum paniculatum) grown in various containers (comprimento da raiz principal (MRL), comprimento da parte aérea (TCL), comprimento total da planta (TPL), massa fresca da raiz principal (TMRFM), massa fresca da parte aérea (TCFM), massa fresca total da planta (TPFM), massa seca da raiz principal (TMRDM), massa seca da parte aérea (TCDM), massa seca total da planta (TPDM) e número de folhas (NF) de mudas de jurubeba (Solanum paniculatum) crescidas em diferentes recipientes). Benjamin Constant, UFAM, 2011.

\begin{tabular}{|c|c|c|c|c|c|c|c|c|c|c|c|}
\hline \multirow{2}{*}{ Evaluations } & \multirow{2}{*}{ Containers } & MRL & TCL & TPL & MRFM & TCFM & TPFM & TMRDM & TCDM & TPDM & \multirow{2}{*}{ NF } \\
\hline & & \multicolumn{3}{|c|}{ (cm) } & \multicolumn{6}{|c|}{$(\mathrm{g} / \mathrm{pl})$} & \\
\hline \multirow{5}{*}{$1^{\text {st }}(38 \mathrm{DAS})$} & PB & $18.71 \mathrm{a}$ & $2.48 \mathrm{a}$ & $21.28 \mathrm{a}$ & $0.24 \mathrm{a}$ & $1.72 \mathrm{a}$ & $1.94 \mathrm{a}$ & $0.020 \mathrm{a}$ & $0.14 \mathrm{a}$ & $0.16 \mathrm{a}$ & $5.50 \mathrm{a}$ \\
\hline & $\mathrm{P} 1$ & $9.73 \mathrm{~b}$ & $0.73 \mathrm{~b}$ & $10.46 \mathrm{~b}$ & $0.08 \mathrm{~b}$ & $0.14 \mathrm{~b}$ & $0.23 \mathrm{~b}$ & $0.007 \mathrm{~b}$ & $0.02 \mathrm{~b}$ & $0.03 \mathrm{~b}$ & $5.33 \mathrm{a}$ \\
\hline & P2 & $6.38 \mathrm{c}$ & $0.70 \mathrm{~b}$ & $7.88 \mathrm{c}$ & $0.02 \mathrm{c}$ & $0.05 \mathrm{c}$ & $0.07 \mathrm{c}$ & $0.004 \mathrm{c}$ & $0.01 \mathrm{c}$ & $0.02 \mathrm{c}$ & $5.00 \mathrm{~b}$ \\
\hline & $\mathrm{P} 3$ & $6.28 \mathrm{c}$ & $0.50 \mathrm{c}$ & $6.75 \mathrm{~d}$ & $0.01 \mathrm{~d}$ & $0.04 \mathrm{~d}$ & $0.05 \mathrm{~d}$ & $0.003 \mathrm{~d}$ & $0.01 \mathrm{c}$ & $0.01 \mathrm{~d}$ & $4.66 \mathrm{c}$ \\
\hline & $\mathrm{CV} \%$ & 8.22 & 10.36 & 7.89 & 20.85 & 9.29 & 8.80 & 12.36 & 20.00 & 17.97 & 8.91 \\
\hline \multirow{5}{*}{$2^{\text {nd }}(45 \mathrm{DAS})$} & PB & $22.05 \mathrm{a}$ & $6.56 \mathrm{a}$ & $28.41 \mathrm{a}$ & $0.30 \mathrm{a}$ & $2.93 \mathrm{a}$ & $3.22 \mathrm{a}$ & $0.050 \mathrm{a}$ & $0.32 \mathrm{a}$ & $0.38 \mathrm{a}$ & $5.50^{\mathrm{NS}}$ \\
\hline & $\mathrm{P} 1$ & $12.80 \mathrm{~b}$ & $1.10 \mathrm{~b}$ & $13.91 \mathrm{~b}$ & $0.09 \mathrm{~b}$ & $0.20 \mathrm{~b}$ & $0.27 \mathrm{~b}$ & $0.010 \mathrm{~b}$ & $0.04 \mathrm{~b}$ & $0.05 \mathrm{~b}$ & $5.50^{\mathrm{NS}}$ \\
\hline & $\mathrm{P} 2$ & $8.05 \mathrm{c}$ & $0.80 \mathrm{c}$ & $8.83 \mathrm{c}$ & $0.02 \mathrm{c}$ & $0.07 \mathrm{c}$ & $0.09 \mathrm{c}$ & $0.007 \mathrm{c}$ & $0.02 \mathrm{c}$ & $0.03 \mathrm{c}$ & $5.50^{\mathrm{NS}}$ \\
\hline & $\mathrm{P} 3$ & $7.46 \mathrm{~d}$ & $0.78 \mathrm{c}$ & $8.18 \mathrm{c}$ & $0.02 \mathrm{c}$ & $0.05 \mathrm{c}$ & $0.07 \mathrm{c}$ & $0.004 \mathrm{~d}$ & $0.01 \mathrm{~d}$ & $0.01 \mathrm{~d}$ & $5.50^{\mathrm{NS}}$ \\
\hline & $\mathrm{CV} \%$ & 12.24 & 6.57 & 10.29 & 37.19 & 28.64 & 28.29 & 39.48 & 27.56 & 27.11 & 0.00 \\
\hline \multirow{5}{*}{$3^{\text {rd }}(52 \mathrm{DAS})$} & PB & $22.20 \mathrm{a}$ & $11.16 \mathrm{a}$ & $34.48 \mathrm{a}$ & $1.38 \mathrm{a}$ & $5.24 \mathrm{a}$ & $6.60 \mathrm{a}$ & $0.120 \mathrm{a}$ & $0.58 \mathrm{a}$ & $0.70 \mathrm{a}$ & $6.00 \mathrm{a}$ \\
\hline & P1 & & & $14.20 \mathrm{~b}$ & & & & & & & $5.83 \mathrm{~b}$ \\
\hline & $\mathrm{P} 2$ & $8.76 \mathrm{c}$ & $1.20 \mathrm{~b}$ & $9.56 \mathrm{c}$ & $0.08 \mathrm{c}$ & $0.15 \mathrm{c}$ & $0.23 \mathrm{c}$ & $0.009 \mathrm{c}$ & $0.02 \mathrm{c}$ & $0.04 \mathrm{c}$ & $6.00 \mathrm{a}$ \\
\hline & $\mathrm{P} 3$ & $8.26 \mathrm{c}$ & $0.95 \mathrm{c}$ & $9.22 \mathrm{c}$ & $0.05 \mathrm{~d}$ & $0.10 \mathrm{~d}$ & $0.15 \mathrm{~d}$ & $0.006 \mathrm{~d}$ & $0.02 \mathrm{c}$ & $0.02 \mathrm{~d}$ & $5.75 \mathrm{c}$ \\
\hline & $\mathrm{CV} \%$ & 16.23 & 8.54 & 11.23 & 27.61 & 20.25 & 20.07 & 39.65 & 30.14 & 32.64 & 3.58 \\
\hline \multirow{5}{*}{$4^{\text {th }}(59 \mathrm{DAS})$} & PB & $24.12 \mathrm{a}$ & $11.35 \mathrm{a}$ & $36.12 \mathrm{a}$ & $2.45 \mathrm{a}$ & $5.94 \mathrm{a}$ & $8.61 \mathrm{a}$ & $0.230 \mathrm{a}$ & $0.80 \mathrm{a}$ & $1.04 \mathrm{a}$ & $6.20 \mathrm{a}$ \\
\hline & $\mathrm{P} 1$ & $16.93 \mathrm{~b}$ & $1.53 \mathrm{~b}$ & $18.58 \mathrm{~b}$ & $0.31 \mathrm{~b}$ & $0.42 \mathrm{~b}$ & $0.74 \mathrm{~b}$ & $0.030 \mathrm{~b}$ & $0.07 \mathrm{~b}$ & $0.10 \mathrm{~b}$ & $6.25 \mathrm{a}$ \\
\hline & $\mathrm{P} 2$ & $10.72 \mathrm{c}$ & $1.38 \mathrm{~b}$ & $11.95 \mathrm{c}$ & $0.13 \mathrm{c}$ & $0.22 \mathrm{c}$ & $0.35 \mathrm{c}$ & $0.010 \mathrm{c}$ & $0.03 \mathrm{c}$ & $0.04 \mathrm{c}$ & $6.10 \mathrm{~b}$ \\
\hline & $\mathrm{P} 3$ & $9.36 \mathrm{~d}$ & $1.13 \mathrm{c}$ & $10.57 \mathrm{c}$ & $0.06 \mathrm{~d}$ & $0.15 \mathrm{~d}$ & $0.21 \mathrm{~d}$ & $0.010 \mathrm{c}$ & $0.03 \mathrm{c}$ & $0.04 \mathrm{c}$ & $6.00 \mathrm{~b}$ \\
\hline & $\mathrm{CV} \%$ & 7.88 & 12.33 & 8.88 & 23.62 & 11.97 & 9.57 & 22.15 & 9.52 & 11.03 & 7.81 \\
\hline \multirow{5}{*}{$5^{\text {th }}(66 \mathrm{DAS})$} & PB & $24.95 \mathrm{a}$ & $12.98 \mathrm{a}$ & $36.45 \mathrm{a}$ & $2.74 \mathrm{a}$ & $6.20 \mathrm{a}$ & $9.07 \mathrm{a}$ & $0.330 \mathrm{a}$ & $0.98 \mathrm{a}$ & $1.33 \mathrm{a}$ & $6.25^{\mathrm{NS}}$ \\
\hline & P1 & $17.17 \mathrm{~b}$ & $1.62 \mathrm{~b}$ & $18.70 \mathrm{~b}$ & $0.34 \mathrm{~b}$ & $0.53 \mathrm{~b}$ & $0.91 \mathrm{~b}$ & $0.040 \mathrm{~b}$ & $0.09 \mathrm{~b}$ & $0.14 \mathrm{~b}$ & $6.25^{\mathrm{NS}}$ \\
\hline & $\mathrm{P} 2$ & $12.77 \mathrm{c}$ & $1.47 \mathrm{~b}$ & $14.11 \mathrm{c}$ & $0.14 \mathrm{c}$ & $0.22 \mathrm{c}$ & $0.37 \mathrm{c}$ & $0.020 \mathrm{c}$ & $0.04 \mathrm{c}$ & $0.06 \mathrm{c}$ & $6.25^{\mathrm{NS}}$ \\
\hline & $\mathrm{P} 3$ & $11.40 \mathrm{~d}$ & $1.28 \mathrm{c}$ & $12.42 \mathrm{c}$ & $0.09 \mathrm{~d}$ & $0.16 \mathrm{~d}$ & $0.24 \mathrm{~d}$ & $0.010 \mathrm{~d}$ & $0.04 \mathrm{c}$ & $0.05 \mathrm{c}$ & $6.25^{\mathrm{NS}}$ \\
\hline & $\mathrm{CV} \%$ & 10.84 & 10.38 & 7.62 & 9.55 & 18.14 & 13.48 & 19.41 & 5.96 & 9.84 & 0.00 \\
\hline
\end{tabular}

${ }^{1}$ Means followed by the same letter, boxes in the column, for each evaluated characteristic in each date of evaluation, do not differ by the Scott-Knott test $(5 \%)$ probability; $\mathrm{ns}=$ not significant; $\mathrm{SP}=$ plastic bag $\left(250 \mathrm{~cm}^{3}\right) ; \mathrm{P} 1=$ plate of 128 cells; $\mathrm{P} 2=$ plate of $200 \mathrm{cells} ; \mathrm{P} 3=$ plate of 288 cells (médias seguidas da mesma letra, maiúscula na coluna, para cada característica avaliada em cada data de avaliação, não diferem entre si pelo teste de Scott-Knott (5\%); ns = não significativo; $\mathrm{PB}=$ saco plástico $\left(250 \mathrm{~cm}^{3}\right)$; $\mathrm{P} 1=$ bandeja de 128 células; $\mathrm{P} 2=$ bandeja de 200 células; $\mathrm{P} 3=$ bandeja de 288 células).

Similar curves to those obtained for fresh matter were observed for the total dry matter (Figures 2A and B). Rodrigues et al. (2010) studied Lycopersicon esculentum (tomato) and observed that the seedlings produced on 72-cell polystyrene trays with $7 \%$ organic compost in the substrate presented greater fresh matter in the canopy, dry matter in the main root and canopy and main root length, compared to those produced on 128- and 200-cell polystyrene trays. Nesmith \& Duval
(1998) and Echer et al. (2000) stated that nutrient absorption is affected by restricted main root development caused by recipient size. According to Medeiros et al. (2008), the better development of seedlings in larger recipients can be explained by the greater availability of substrate that may allow better main root development, thus increasing the area for nutrient absorption.

Smaller cells have smaller spaces for main root development, and it is more difficult to supply factors such as air, water and nutrients that ensure production and the normal seedling growth and development (Reghin et al., 2007).

In proportional terms, the TPDM:TPFM ratio for the seedlings grown in each one of the recipients studied showed that for both the cocona and jurubeba plants, dry matter percentage contribution increased until 45 DAS in the fresh matter characteristics assessed. For the plastic bag, this increase continued to be observed until 

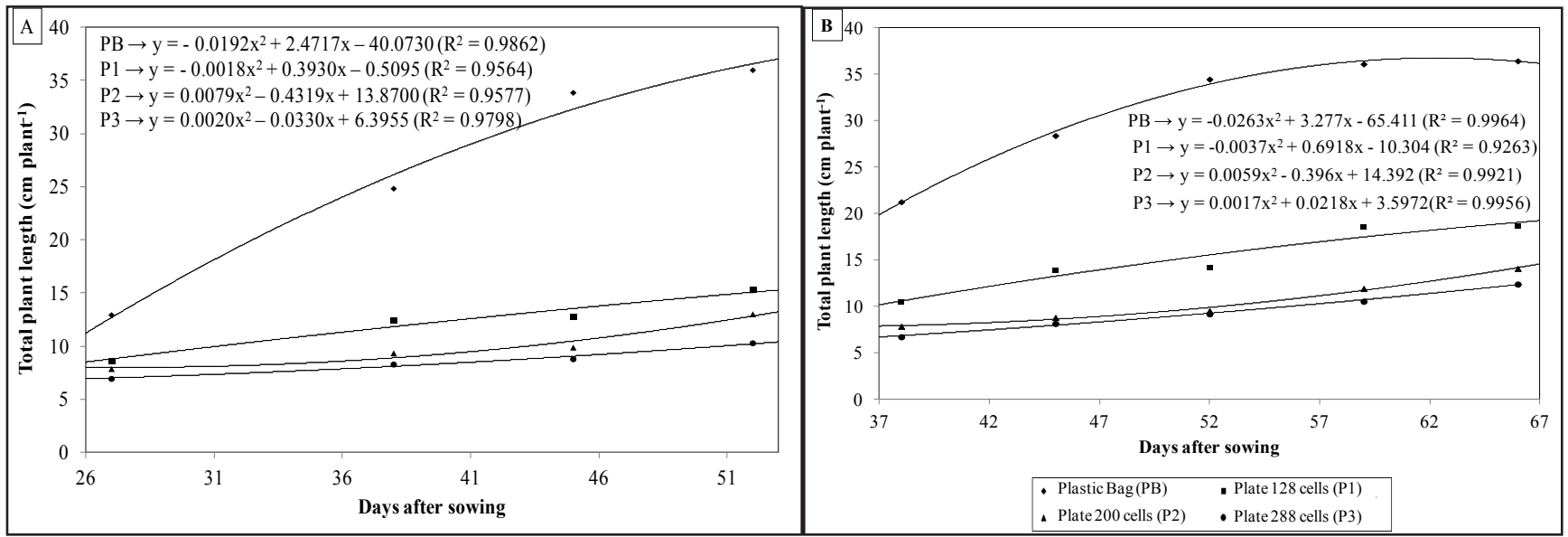

Figure 1. Total plant length of cocona (A) and jurubeba (B) seedlings, using various containers (plastic bag, plates of 128,200 and 288 cells), evaluated in different dates: cocona at 27,38, 45 and 52 days after sowing date and jurubeba at 38, 45, 52, 59 and 66 days after the sowing (comprimento total de mudas de cubiu (A) e jurubeba (B), semeando em diferentes recipientes (saco plástico, bandejas de 128, 200 e 288 células), avaliadas em diferentes datas: cubiu aos 27, 38, 45 e 52 dias após a semeadura e jurubeba aos 38, 45, 52, 59 e 66 dias após a semeadura). Benjamin Constant, UFAM, 2011.
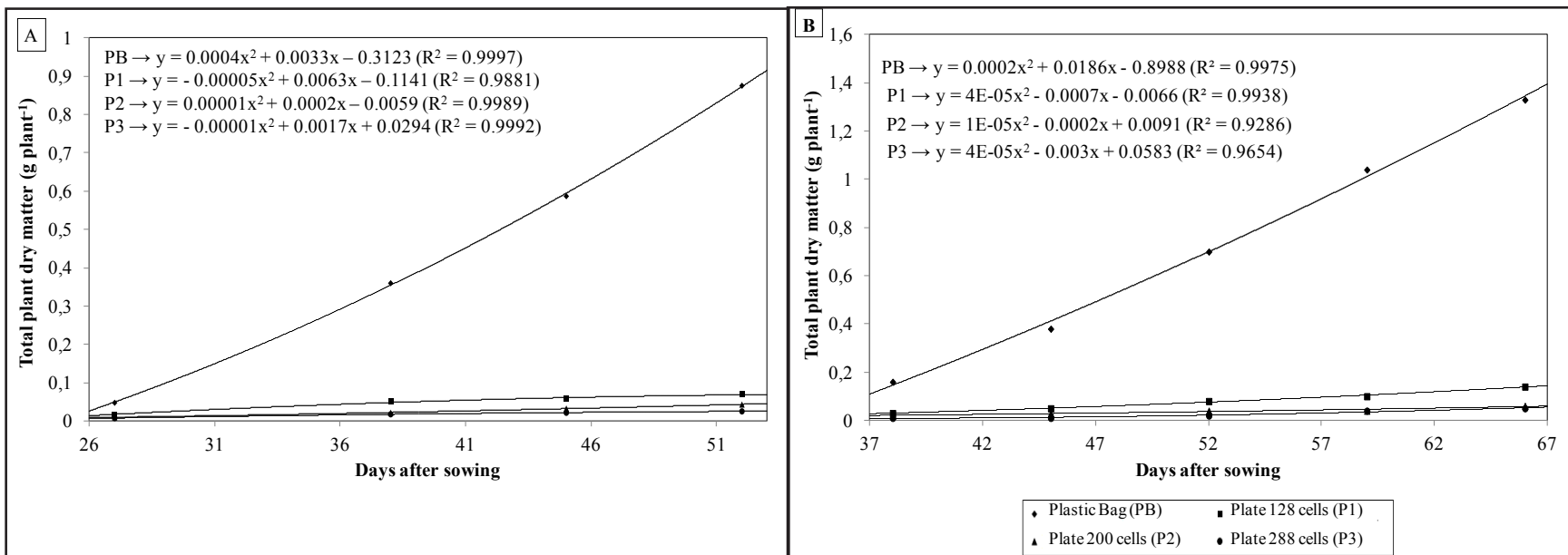

Figure 2. Total plant dry matter of cocona (A) and jurubeba (B), using various containers (plastic bag, plates of 128,200 and 288 cells), evaluated at different dates: cocona at 27, 38, 45 and 52 and jurubeba at 38, 45, 52, 59 and 66 days after sowing date (massa seca total de mudas de cubiu (A) e jurubeba (B), provenientes de diferentes recipientes (saco plástico, bandejas de 128, 200 e 288 células), avaliadas em diferentes datas: cubiu aos 27,38, 45 e 52 dias após a semeadura e jurubeba aos 38, 45, 52, 59 e 66 dias após a semeadura). Benjamin Constant, UFAM, 2011.

the last assessment of both the species. The 128- polystyrene trays tended to stabilize in the following assessments. However, this ratio decreased for the 200- and 288-cell polystyrene trays.

For the characteristic assessed of number of leaves per seedling, the polynomial regression analysis on the different assessment dates, for the cocona crop, showed quadratic performance for each one of the treatments assessed. This performance enabled maximum points to be obtained above 37 DAS for this characteristic in all the treatments assessed (Figure
3A). Simple comparison among the treatments for this crop showed that up to $45 \mathrm{DAS}$, the seedlings produced in larger recipients usually had a larger number of leaves. However, at the last assessment (52 DAS), reductions were observed in the number of leaves of these in all the treatments (Table 1).

For the jurubeba, there was little effect of the size of the recipients on seedling leaf emission (Figure 3B). This was because all the treatments assessed presented a very close number of leaves per plant and no treatment was outstanding in promoting the development of a greater number of leaves (Table 2). However, aspects of nutritional deficiency, such as those observed for the cocona crop, were also observed for the jurubeba in all the treatments assessed, but on different days after sowing.

Thus the results obtained in the present study showed that cocona seedlings produced in plastic bags can be kept in these recipients up to 45 DAS without any harm being observed to the plant growth and development characteristics.

For the jurubeba crop the plastic bag 


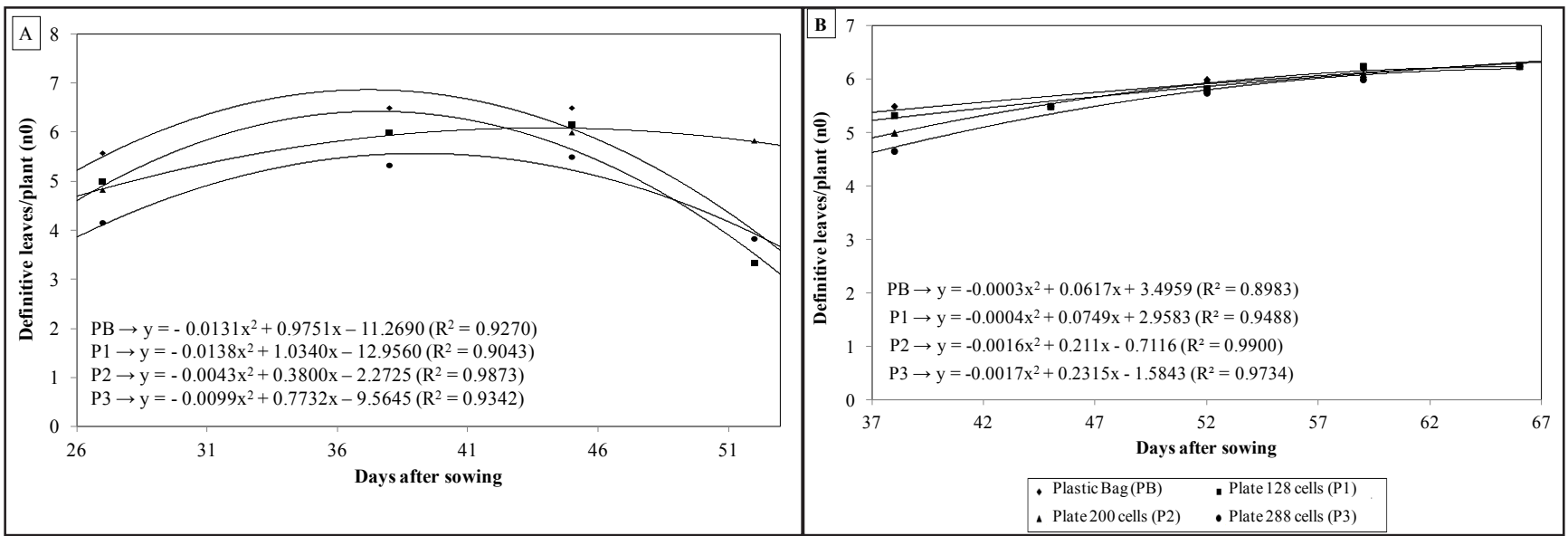

Figure 3. Number of definitive leaves per plant of of cocona (A) and jurubeba (B) seedlings, using various containers (plastic bags, plates of 128, 200 and 288 cells), evaluated in different dates: cocona at 27, 38, 45 and 52 and jurubeba at 38, 45, 52, 59 and 66 days after sowing (número de folhas de mudas de cubiu (A) e jurubeba (B), provenientes de diferentes recipientes (saco plástico, bandejas de 128, 200 e 288 células), avaliadas em diferentes datas: cubiu aos 27, 38, 45 e 52 dias após a semeadura e jurubeba aos 38, 45, 52, 59 e 66 dias após a semeadura). Benjamin Constant, UFAM, 2011.

was a recipient that in general permitted better development conditions for the seedlings. However, regardless of the recipient used for the species, the seedling should be transplanted before 66 DAS.

\section{REFERENCES}

AUGUSTO E. 2002. Maná-cubiu: a fruta dos deuses. Guia Rural \& Negócios, novembro 2002. Disponível em: http://www.bioflorestal. com.br/mana_novo.htm. Acesso em: 22 jul. 2004.

BELFORT CC; RODRIGUES GM; NERY EB; SETÚBAL JW; THÉ FW; ALMEIDA RB; LIMATR; CARVALHO JF. 2005. Desempenho de mudas de melancia obtidas em dois tipos de bandejas, em quatro estágios de crescimento, com e sem adubação. In: CONGRESSO BRASILEIRO DE OLERICULTURA, 45. Resumos... Fortaleza: SOB (CR-ROM).

BEZERRA FC; AQUINO AJS. 2003. Tamanho do recipiente na produção de mudas de melão. In: CONGRESSO BRASILEIRO DE OLERICULTURA, 43. Resumos... Recife: SOB (CR-ROM).

BRASIL. Ministério da Agricultura, Pecuária e Abastecimento. Secretaria de Desenvolvimento Agropecuário e Cooperativismo. 2010. Manual de hortaliças não-convencionais. Brasília: Mapa. 92 p.

BRITO AB. 2005. Influência de tipos de bandejas, estádios de crescimento e adubação química, no desempenho de mudas de abobrinha (Cucurbita pepo L.). Teresina: UFP. 32p (Tese mestrado).

ECHER MM; ARANDA AN; BORTOLAZZO ED; BRAGA JS; TESSARIOLI NETO J. 2000. Efeito de três substratos e dois recipientes na produção de mudas de beterraba. In: CONGRESSO BRASILEIRO DE OLERICULTURA, 40. Resumos... Brasília:
SOB (CR-ROM).

FILGUEIRA FAR. 2008. Novo manual de olericultura: agrotecnologia moderna na produção e comercialização de hortaliças. Viçosa: UFV. 421p.

LOPES JC; PEREIRA JD. 2005. Germinação de sementes de cubiu em diferentes substratos e temperaturas. Revista Brasileira de Sementes 27: 146-150.

MEDEIROS MA; FREITAS AVL; GUIMARÃES IP; MADALENA PB; MARACAJÁ PB. 2008. Produção de mudas de tomateiro em bandejas multicelulares e irrigadas com efluente de pisicultura. Revista Verde 3: 59-63.

NESMITH DS; DUVAL JR. 1998. The effect of container size. HortTechnology 8: 495-498.

OLIVEIRA RMB; ARLINDO DM; PEREIRA IE. 2004. Avaliação de diferentes tamanhos de sacos de polietileno sobre o desenvolvimento de mudas de leucena (Leucaena leucocephala (Lam).Dewit). Revista de Biologia e Ciências da Terra 4: 1-4.

REGHIN MY; OTTO RF; VINNE JV. 2003. Tamanho da célula de diferentes bandejas na produção de mudas e no cultivo do pak choi na presença e ausência do agrotêxtil. Scientia Agraria 4: 61-67.

REGHIN MY; OTTO RF; OLINIK JR; JACOBY CFS. 2007. Produtividade da chicória (Cichorium endivia L.) em função de tipos de bandejas e idade de transplante de mudas. Ciência e Agrotecnologia 31: 739-747.

RESENDE GM; YURI JE; MOTA JH; SOUSA RJ; FREITAS AC; RODRIGUES JÚNIOR JC. 2003. Efeitos de tipos de bandejas e idade de transplantio de mudas sobre o desenvolvimento e produtividade da alface americana. Horticultura Brasileira 21: 558563.

RODRIGUES ET; LEAL PAM; COSTA E; PAULA TS; GOMES VA. 2010. Produção de mudas de tomateiro em diferentes substratos e recipientes em ambiente protegido. Horticultura Brasileira 28: 483-488.

SANTOS NETO OD; KARSBURG IV;
YOSHITOME MY. 2006. Viabilidade e germinabilidade polínica de populações de Jurubeba (solanum paniculatum 1.). Revista de Ciências Agro-Ambientais 4: 67-74.

SEABRA JÚNIOR S; GADUN J; CARDOSO AII. 2004. Produção de pepino em função da idade das mudas produzidas em recipientes com diferentes volumes de substrato. Horticultura Brasileira 22: 610-613.

SILVAACF; VIZZOTTO VJ. 2001. Espaçamento e método de cultivo adequados aumentam a produtividade e a qualidade da beterraba. Agropecuária Catarinense 6: 1006-1011.

SILVA DFP; ROCHA RHC; SALOMÃO LCC. 2011. Postharvest quality of cocona (Solanum sessiliflorum Dunal) stored under ambient condition. Revista Ceres 58: 476-480.

SILVA FILHO DF; ANUNCIAÇÃO CJ; NODA H; REIS OV. 1996. Variabilidade genética em populações naturais de cubiu da Amazônia. Horticultura Brasileira 14: 9-15.

SILVA FILHO DF; YUYAMA LKO; AGUIAR JP; OLIVEIRA MC; MARTINS LHP. 2003. Caracterização e avaliação do potencial agronômico e nutricional de etnovariedades de cubiu (Solanum sessiliflorum Dunal) da Amazônia. Acta Amazonica 35: 399-406.

YUYAMA LKO; PEREIRA ZRF; AGUIAR JPL; SILVA FILHO DF; SOUZA RFS; TEIXEIRA AP. 2005. Estudo da influência do cubiu (Solanum sessiliflorum Dunal) sobre a concentração sérica de glicose. Revista Instituto Adolf Lutz 64: 232-236.

YUYAMA LKO; MACEDO SHM; AGUIAR JPL; SILVA FILHO D; FAVARO KDIT; VASCONCELLOS MBA. 2007. Quantificação de macro e micro nutrientes em algumas etnovariedades de cubiu (Solanum sessiliflorum Dunal). Acta Amazônica 37: 425-430.

YUYAMA LKO; PANTOJA L; MAEDA RN; AGUIAR JPL; SILVA SB. 2008. Desenvolvimento e aceitabilidade de geléia dietética de cubiu (Solanum sessiliflorum Dunal). Ciência e Tecnologia de Alimentos 28: 929-934. 